\title{
HOW COMMUNITY BASED INFLUENCE SELF ESTEEM IN RURAL TOURISM DEVELOPMENT
}

\author{
Grace AMIN* and Filda RAHMIATI \\ Management Study Program, President University, Bekasi, Indonesia \\ *grace_amin@president.ac.id
}

\begin{abstract}
Indonesia is wellknown as tourist magnetism due to exotic nature, culture and local people's hospitality. There are many tourist destinations that always be visited by local tourists and foreigner. Some of the destinations are managed by local citizens but some of them also managed by external parties or foreigners. The purpose of this paper was analyzing the contribution of local people in tourism development. Qualitative method was used to collect the information through in depth interview and participatory observation. This research found that through community development, the local people finally believe on their own capabilities. Local citizens are willing to support the development of tourism in their area by giving their resources. The increasing of local community's self esteem can influence the competitive advantage of rural tourism.
\end{abstract}

Keywords: Self Esteem, Community based tourism, Sustainability Rural Tourism

\section{BACKGROUND}

Tourism is one of the sector that growing fast and influence economic development in many countries. This potetial sector has to be managed well in order to generate higher result (Rahmiati et al., 2019), (G, 2015). Potential tourist attractions, such as beach, coral, beautiful islands, local cultures and good hospitality, those had by Indonesia will be a great value and allure. By the tourism development, foreign exchange earning of foreign tourists have increase every year (Amin et.al, 2020).

For years, tourism development was focused on urban tourism but nowadays Indonesian goverment also focus on rural tourism. Rural tourism and urban tourism, has a different characteristic. Rural tourism is a concept where rural area offers an overall atmosphere that reflect the authenticity of the countryside. This concept is able to upgrade the prosperity of local people in that area. (Deputi Bidang Pengembangan Industri dan Kelembagaan Kementerian Pariwisata Republik Indonesia, 2019). The main principle applied by rural tourism is how the noble values of both tradition and culture that are inherent and have become characters must be respected stay protected. Environmental conservation is also concerned (Syah, 2017).

The Minister of Tourism and Creative Economy, Sandiaga Uno, stated that the sustainable development of tourism industry will be focused on rural tourism. The local goverments asked to improve the competency of human resources and explore many potential resources in their area. Not all of the villages implement rural tourism program have the same capacity to grow. Sandiaga Uno also drive local citizens in potential village tourism to adapt with digital technology system in order to be able to compete with other countries. (kompas.com, 2021) By digital marketing, rural tourism programs will be known by many people around the world. When many local or international tourists come and visit lovely villages that promoted, the regional income must be increase and of course it also will influence Indonesian Gross Domestic Product (GDP).
In many tourism development, economic, commercial and logistical issues, such as infrastructure, quality of product and human skills, will be significant factors. The readiness of that village to improve its capabilities can be challenging. One of the advantages of rural tourism is local management. The emphasis on the local can help to generate regional development (Okech et al., 2012).

Community based tourism arose from the need to value local culture and evolve socioeconomic sectors.(da Conceição Walkowski et al., 2019). Community means a group of people living in a spesific area, so community based tourism can be defined as a type of tourism that is managed and owned by the community, with the purpose to introduce visitors about this community and local ways of life. The fundamental idea of Community based tourism is sustainable development, where community participation in implementation and decision making processes creates conditions to developing learning capacities and communities empowerment. Local citizens are asked to get involve, use all of their potency (Khartishvili et al., 2021). Considering these benefits, self esteem in tourism development is the key factor. Self esteem relates with pride, engagement and commitment. When people have high level of self esteem, they will give their best effort to manage their village. (Ginting et al., 2019)

\section{Self esteem}

Self esteem can be defined as individual's evaluation of the self. It is composed of two dimensions, competence and worth. Competence can be explained as the degree to which people see themselves as capable, while worth is the degree where individuals feel that they are person of value. The purpose of self esteem is to function as a system that monitoring people's reaction to self. It also can be used as self motive, outcome and buffer of self. (Cast \& Burke, 2002), (Harris \& Orth, 2020).

The self is composed by multiple identities that reflect the various social positions that people occupies in the larger social structure. Identity reflect an individual's description of themselves in a particular position or role. Self 
verification occurs when meanings in the social situation match with meanings in an identity. The verification of an identity produce feelings of competency and worth which increasing self esteem. When people within group receive self-verifying feedback (through reflected appraisal and social comparisons), feeling that they are accepted and valued by others are reinforced and increasing self esteem. When individuals reflect on their behavior and observe that they have been succsessful matching their identity and social situation, the efficacy based self esteem also will be influenced (Cast \& Burke, 2002).

Self esteem is positively associated with self reported positive emotions, happiness and satisfaction. Self esteem will influence well being and mental health, job performance, physical health, interpersonal relationship, People with high level of self esteem is linked to healthy psychological functioning. They claim to be more attractive and likeable to have better relationship. High self esteem makes people more willing to speak up and show their strength. Contrast with that, people with low level of self esteem is related to negative emotions, such as depression, anxiety, anger, loneliness and more external locus of control (Baumeister et al., 2003), (Hepper, 2016).

\section{Community based tourism}

Community based tourism (CBT) refer to community development tool that strengthens the ability of local communities to manage tourism resources while ensuring the potential local community's participation in tourism sector. By doing community based tourism, the income of local people will be increase. It also can preserve local culture, empower local people by education and protect the environment (Regmi et al., 2015), (Singgalen et al., 2019), (Amin et al., 2020), (Partington \& Totten, 2012). The involvement of local communities in the tourism management strategies will influence the sustainability of tourism because they are going to respect and maintain their traditional lifestyle and values (Thetsane, 2019). The link between social relationship and self esteem is truly reciprocal. The great social relationship will increase the self esteem, vice versa. (Harris \& Orth, 2020)

The participation of community can be devided into three stages, decision making process, implementation and evaluation stages. In decision making stages, local people will be asked to join in the meeting that discuss about the strategies. After they prepare the good plans, the next stage will be implementation where the real participation of local communities become important. It can be classified as thought contributions, material and real action as the project member. The last stage is evaluation that allow local people to give their feedback toward the implementation of their strategies. These inputs are going to be used as the improvement steps for the future. (Singgalen et al., 2019). Local citizens can be involved in many ways such as local entrepreneurship, employment in tourism sector, park and land uses (G, 2015), (da Conceição Walkowski et al., 2019), (Partington \& Totten, 2012).

\section{Sustainable Rural Tourism}

Rural tourism is defined as any form of tourism that take place in the countryside. Currently people have turned to natural, preserved and fresh environment as their destination. Many tourists prefer rural area because they can spent their leisure time and connect to the nature. Rural tourism provide many activities such as nature activities, agro-tourism, eco-tourism, cultural tourism, rural experience and other combination of special tourism packages. (Podovac \& Jovanović Tončev, 2016). The purpose of rural tourism are to increase the benefits to citizens from rural areas and their participation in the development of tourism sector (Okech et al., 2012).

Sustainable rural tourism refer to activities that contribute to positive economic and social development of rural areas without violate the natural environment and local traditions. It contributes to the realisation of some objectives such as preservation of natural landscape, culture and character of local people, sustainable development of rural economy and tourism industry Podovac \& Jovanović Tončev, (2016); Syah, (2017) stated there are many forms of rural tourism such as gastronomy (culinary), adventure, agrotourism, cultural, ecotourism, marine and spiritual tourism. The success of rural tourism development depends on community leadership, strategic plans, understanding, coordination among parties and active participation of local citizens (G, 2015).

\section{METHOD}

Qualitative approach was used in this research. Researchers got the information from local goverment, local citizens and stakeholders (POKDARWIS, in Desa Wisata Taro, Bali by in-depth interview and participatory observation. Desa Wisata Taro is one of the famous ruraltourism destination in Indonesia. Desa Wisata Taro uses its capabilities, as eco-spiritual destination, to attract local tourists and foreigner. research was held at Desa Taro, Bali.

\section{RESULT AND DISCUSSION}

Based on the information got from the local citizens, goverment (Banjar adat dan Banjar dinas) and stakeholders in Desa Wisata Taro, the implementation of community based tourism has been running well. The local goverment engages the local people in managing their environment. They discuss the strategic plans that will be used to develop their rural tourism. The local goverment use bottom - up method where they always digging up the ideas from local citizens because they are the one that know about this place. By giving the opportunities to share the ideas freely, the local people in Desa Wisata Taro feel appreciated. Local goverment also support the development of this rural tourism program by providing fund and good infrastructure.

The empowerment of local people in Desa Taro also bring a positive psychological impact. According to the local people that joined in the interview, they were 
not confidence previously. They did not believe on their capabilities and had low self esteem. Some of the local people only gave their land to the external parties to be managed and they did not get any profit. One of young local people in this village finally became an agent of change in this village. He drives other people in that village to be proud of themselves and use their capabilities to develop their own village. When local people asked to see the potential resources around them, finally they found many power that had not managed before. It was not easy in the begining to increase their self esteem because they had negative mindset before. They never think about local resources that can be carried out. Actually they have wide land but they did not use it as the tourist attraction. By doing brainstorming, many creative ideas arose and finally they tried to implement those ideas. The beautiful natural scenery, activities of local people, spiritual and culture in the village become the main value of their marketing strategy. Local people in Desa Taro finally aware and proud of their uniqueness. They do not use other's standard but they create their own successful standard.

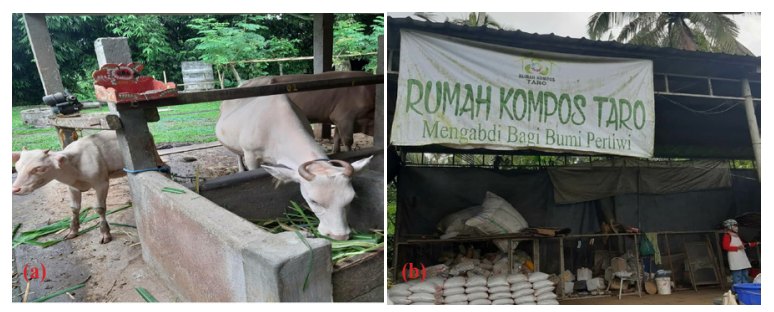

Figure 1. (a) White cow conservation \& (b) Waste management

Community based program aslo teach local people in Desa Taro to support each other and expand their competences. They learn something new to improve their skills such as other language, local handycrafts and digital marketing. These local communities also explore their nature and promote new concepts of rural tourism for instance the fireflies garden, homestays that provide nature activities of rural citizens to the tourists, training local foods for tourist and tracking to see their nature. Recognition for the rural tourism programs, held by Desa Wisata Taro, come from many parties and those recognition finally make the level of local people's self esteem become higher. Nowadays they are ready to compete with the global tourism sector by showing off their local culture and beautiful nature. The confidence smile can be seen in their face. They can speak up bravely and announce their hometown. The development of their village also bring a great impact towards economic, education and other sectors. There are many young generations in Desa Taro that motivated to continue their study in order to evolve their hometown. They combine the new concept that they learn with the local culture and nature. They try not to harm the environment. One of the real program to maintain the sustainable environment is their own waste management place. People in this village, collect and divide the garbages so they can be processed easily.

\section{CONCLUSION}

The development of tourism sector not merely depends on modern sources. Empowering local citizens in rural areas that have potential resources also can be used as the strategic plan. Community based in rural tourism that fully supported by goverment will influence not only sustainability tourism but also socioeconomic development, education, sustainable environment and positive self esteem of the citizens. The growth of tourism industry can reducing the poverty by creating employment opportunities. The increasing of visitors will affect the Indonesian economic and reputation.

There are some recommendation for the improvement of community based in rural tourism, namely :

1. Strive for the digital approach in tourism. It can expand the information worldwide.

2. Encourage more women and youth participation

3. Engage universities or education sector to support rural tourism by giving beneficial trainings.

\section{ACKNOWLEDGEMENT}

This study was funded by the Ministry of Education, Culture, Research and Technology Directorate General of Higher Education.

\section{REFERENCES}

Amin, G., Rahmiati, F., Ismail, Y., Simatupang, T., \& Larso, D (2020). Community Participation in Tourism Development. Proceeding of International Conference on Family Business and Entrepreneurship. http://e-journal.president.ac.id/ presunivojs/index.php/ICFBE/article/view/1398

Baumeister, R. F., Campbell, J. D., Krueger, J. I., \& Vohs, K. D. (2003). Does High Self-Esteem Cause Better Performance, Interpersonal Success, Happiness, or Healthier Lifestyles? Psychological Science in the Public Interest, 4(1), 1-44. https://doi. org/10.1111/1529-1006.01431

Cast, A. D., \& Burke, P. J. (2002). A theory of self-esteem. Social Forces, 80(3), 1041-1068. https://doi. org/10.1353/sof.2002.0003

da Conceição Walkowski, M., dos Santos Pires, P., \& Torres Tricárico, L. (2019). Community-based tourism initiatives and their contribution to sustainable local development. Journal of Sustainable Tourism and Entrepreneurship, 1(1), 55-67. https://doi. org/10.35912/joste.v1i1.203

Deputi Bidang Pengembangan Industri dan Kelembagaan Kementerian Pariwisata Republik Indonesia. (2019). Pengembangan Wisata Pedesaaan \& Wisata Perkotaan: Rancangan Pola Perjalanan.

G, N. (2015). Local Community Involvement in Tourism: A Content Analysis of Websites of Wildlife Resorts. Atna - Journal of Tourism Studies, 10(1), 13-21. https://doi.org/10.12727/ajts.13.2 
Ginting, N., Rahman, N. V., \& Nasution, A. D. (2019). Aspects of self-esteem in the tourism development in karo regency, North Sumatera, Indonesia. Journal of Urban and Regional Analysis, 11(2), 173-183. https://doi.org/10.37043/JURA.2019.11.2.4

Harris, M. A., \& Orth, U. (2020). The link between selfesteem and social relationships: A meta-analysis of longitudinal studies. Journal of Personality and Social Psychology, 119(6), 1459-1477. https://doi. org/10.1037/pspp0000265

Hepper, E. G. (2016). Self-Esteem. Encyclopedia of Mental Health: Second Edition, December 2016, 80-91. https://doi.org/10.1016/B978-0-12-3970459.00076-8

Khartishvili, A., Khartishvili, L., Mitrofanenko, T., Muhar, A., \& Penker, M. (2021). Issues with Applying the Concept of Community-Based Tourism in the Caucasus Issues with Applying the Concept of Community-Based Tourism in the Caucasus. 40(1).

Okech, R., Haghiri, M., \& George, B. (2012). Rural Tourism as a Sustainable Development Alternative: An Analysis with Special Reference to Luanda, Kenya. CULTUR: Revista de Cultura e Turismo, 6(3), 36-53.

Partington, J., \& Totten, M. (2012). Community sports projects and effective community empowerment: A case study in Rochdale. Managing Leisure, 17(1), 29-46. https://doi.org/10.1080/13606719.2011.638 205
Podovac, M., \& Jovanović Tončev, M. (2016). The Importance of Sustainable Rural Tourism Development in Serbia. January 2016, 575-581. https://doi.org/10.15308/sinteza-2016-575-581

Rahmiati, F., Ismail, Y., Amin, G., Simatupang, T., Larso, D., \& Othman, N. A. (2019). Tourism Value Chain Activities Model for Competitive Advantage Measurement. 98(Icot), 43-47. https://doi. org/10.2991/icot-19.2019.10

Regmi, K. D., Walter, P. G., ZDEL, Hinkin, T. R., Tracey, J. B., Enz, C. A., Riris, R. H., Pixler, P. W., عرماع, د. و. p., Treloar, C., Champness, S., Simpson, P. L., Higginbotham, N., Description, A., Outcome, E., Anderson, D. ., Krathwol, L. ., Maháthera, N., Geometry, R., ... Shukor, M. S. (2015). Handbook on Community Based Tourism "How to Develop and Sustain CBT", December 2009. In Tourism (Vol. 7, Issue 5). http://dx.doi.org/10.1080/1472404 9.2015.1118108

Singgalen, Y. A., Sasongko, G., \& Wiloso, P. G. (2019). Community participation in regional tourism development: a case study in North Halmahera Regency - Indonesia. Insights into Regional Development, 1(4), 318-333. https://doi. org/10.9770/ird.2019.1.4(3)

Syah, F. (2017). Strategi mengembangkan desa wisata. Seminar Nasional Multi Disiplin Ilmu Ke-3(Sendi_U 3) 2017, 3(Sendi_U 3), 335-341. 